\title{
COMPARATIVE LITERARY WORKS, LANGUAGE LEARNING AND CHARACTER BUILDING OF LEARNERS
}

\author{
Samuel Jusuf Litualy \\ samly_56@yahoo.co.id \\ and \\ Henderika Serpara \\ German Language Department, Pattimura University, Ambon - Indonesia
}

\begin{abstract}
This paper aims to express efforts to use comparative literary works as a medium in language learning, and at the same time as a means for the formation of the character of learners. The benefits of comparative literature, among others: (1) as the basis of the study of cross-cultural literary works, (2) as the basis or basis of language skills learning (Sprachfertigkeiten) namely: listening (HörverständnisSprechfertigkeit), reading-writing (Leseverständnis-Schreibfertigkeit), (3) as a means of strengthening character education. As the basis for cross-cultural text studies, comparative literary works can be used to compare cultures between nations. As the basis of language learning, comparative literary works, has a uniqueness that is not possessed by other linguistic teaching materials, because the language of literary works has a connotative characteristic (figurative), contains majas, and prioritizes the characteristics of narrative discourse. Language in literary works prioritizes its main function, which is communicative function and suitable to be used to teach language skills. Furthermore, as a means of strengthening character education, literary works are worthful, which can be used to provide value strengthening for learners as the future generation of the nation.
\end{abstract}

Keywords: comparative literary works, language learning, character building, learners

\section{Introduction}

The decline of values: ethical, moral and social today has shed many components of this nation, and must already be prevented and addressed. The moral and social values contained in Pancasila and the 1945 Constitution are only reference materials that are difficult to apply in real life. The noble values of this nation's culture seem to have been eroded to the point. The religious values found in the scriptures of all religions are no longer a good example. The problem of $\mathrm{KKN}$ (corruption, collusion, and nepotism) that occurred during the new order in various government and private agencies until now seems to be a difficult thing to avoid and tends to be considered a trend. Dishonesty and injustice have permeated and infiltrated the world of education. In the past decades, many students have done the cheating and some become jockeys during school exams and national exams as if it had become a regular spectacle. Man is no more longer ashamed or guilty of what he has done. The culture of violence, fights, murders and social 
anarchism, both directly and through cyberspace, such as insulting each other, demeaning each other, hoaxes, and so on, continues to aggravate the sociocultural condition of this nation.

The values of local wisdom are famous for being friendly, polite, respectful and respectful, wise, wise, and religious as if eroded by an instant and modern lifestyle. People are very easily ignited emotions, grumpy, brutal, rude, and vulgar without being able to control themselves. This phenomenon hints that the character of the nation's people has weakened, which is famous for being friendly, polite, noble, and virtuous. This indicates that ethical and moral education in the framework of the formation of the character and character of students in this country has long been neglected in the learning process. The orientation of education in Indonesia has been misguided. The reason is because our education is more likely to focus on the cognitive aspect alone, while other aspects are neglected which causes the learner's learning orientation solely to achieve high scores, thus encouraging them to pursue high scores in improper ways, such as cheating, plagiarizing, and so on (Megawangi, 2005: 5). This suggests an all-instant indication of a learning orientation that is now more likely to be a product or final result, otherwise neither nor less appreciative of the process of acquiring science (Darmaningtyas, 2005: 210).

This fact hints that the values that this cultured nation wants to realize through Presidential Regulation Number. 87 of 2017 dated September 6, 2017 on Strengthening Character Education (PPK), namely: religious values, honest, integrity, tolerant, discipline, hard work, creative, independent, democratic, curiosity, national spirit, love of the homeland, appreciate achievements, communicative, peace-loving, fond of reading, environmental care, social care , gotong-royong, and responsible and Regulation of the Minister of Education and Culture No. 22 of 2020 concerning the Strategic Plan of the Ministry of Education and Culture, Pancasila Students are the embodiment of Indonesian students as lifelong students who have global competence and behave in accordance with the values of Pancasila. The six main characteristics of Pancasila students: (1) faith, trust in God almighty, and noble character, (2) global diversity, (3) cooperation, (4) self-reliance, (5) critical and creative reasoning, are just difficult dreams to achieve. Whereas these values can interact with each other, develop dynamically so as to form an established personal integrity. Strengthening Character Education and Student Pancasila is an educational movement under the responsibility of the education unit to strengthen the character of learners through harmonization of taste, thought, and sports with the involvement and cooperation between educational units, families, and communities as part of the National Movement for Mental Revolution (GNRM).

In addition to the application and establishment of Presidential Regulation No. 87 of 2017 for the strengthening of the character of the nation's most special students, one solution that is considered effective enough to overcome the problem of deterioration of character, ethics and morals is the need for the application of learning literary works compared to learners. In comparative literary works (both national literary works, and foreign literary works) contained a moral message. Literary works are an extraordinarily beautiful product of 
culture, and in many ways comparative literary works affect other areas of human life, such as: social life, politics, economics, society, and religion (Alisjahbana, 1985: 13-14), in addition to being able to provide the collection of humanities to produce humanist, moral, and subtle-hearted human beings for society.

The Indonesian nation has long been known as a cultured, friendly, civilized and dignified nation. Thus, the situation as described above, certainly not favorable for the future of the nation, especially in creating the next generation of the nation's future who are smart, skilled, intellectual, wise, virtuous, noble, highly civilized, love the homeland and always devoted to God almighty. The Indonesian nation has long been known as a cultured, friendly, civilized and dignified nation. Thus, the situation as described above, certainly not favorable for the future of the nation, especially in creating the next generation of the nation's future who are smart, skilled, intellectual, wise, virtuous, noble, highly civilized, love the homeland and always devoted to God almighty.

In such conditions, it takes a paradigm of psychiatric education oriented to the character of the nation, which not only pursues cognitive interests (thought, reason, and logic), but also pays attention to and integrates moral issues and ethical nobility.

There are several reasons why comparative literary works are chosen and juxtaposed with language learning and the formation of student characters. First, the learning of language skills (listening, speaking, reading and writing) can be developed through comparative literary works. Second, comparative literary works are an integral part of people's life and culture in a cross-cultural perspective. The presence of comparative literary works in the midst of people's lives is influenced by social and cultural values. Third, Comparative literary works are a picture of life. Comparative literary works are the result of thinking about life in the form of fiction and created by the author to expand, deepen and refine the reader's passion for one side of people's lives that it presents. The authors of literary works are members of the community, come from the community and are in the community. Thus, the creation of a literary work by an author directly or indirectly is a freedom of cultural attitude of the author to the reality experienced. Fourth, literary works are tools for educating, which, when associated with their message and content, are ethical means (Kutha Ratna, Nyoman, 2005: 447). Fifth, comparative literary works contain the values of psychiatric education that can be used to realize and improve the character of the nation.

In an effort to establish the character of this nation, comparative literary works can be used as one of the media or means of psychiatric education. Because in the literary work of comparison contained the value of character, ethics, morals, and social related to human life.

\section{Comparative Literary}

Literary works are often understood variously and some even humanely as the author's design or imagination without basis, but in fact not so. To straighten out the above understanding, it is necessary to put forward the literary understanding put forward by some literary experts. Tirto Suwondo (2003: 5-6) 
suggests that literary works are the result of human creative activities related to imagination, intuition, and abstraction of life that uses language as its medium. Semi (1988: 8) gives an understanding that literary works are a form and the result of creative art work whose object is human and its life by using language as its medium. Wellek and Warren (1990: 3) argue that, literary works are an activity, a work of art. According to Recoeur (twisted Piliang, 2004: 73-74) literary works relate to the mutual-circular reality which means that some of the basic material of fiction comes from the real world, combined with imagination and fantasy, which eventually turns that reality into posreality. In relation to this, Mahayana (2005: 129) suggests that literary works and works of art, regardless of type, are all derived from facts and facts that occur in people's lives.

Based on the above understanding formulations, it can be concluded that the essence of literary works is experience, the author's observation of the events around him, which is then processed imaginatively, creatively, artistically so that it becomes a work that contains the values of life. The work is then delivered in beautifully assembled language through its dictions, making it interesting to read. The experiences and observations of literary authors in their work cover all aspects of life in the social, cultural, political, community, and individual fields.

One of the fields of literature that can be used to know and understand cross-national culture is comparative literature. Comparative literature in French is referred to by Villemain (1829) as "literature comparce", while J.J. Ampere (1848) calls it "comparative histoire". Wellek and Warren (1990) referred to it as "comparative literature". While Hendrik Birus (2008) called it by the term Allgemeine und Vergleichende Literaturwissenschaft (Comparative), which is interpreted as the science of literature as a whole and its comparison. It is said that the mastery of literary knowledge should be followed up by conducting comparative literary studies, among others, cross-cultural literary studies, thus enriching knowledge and insights especially related to the cultural content of the work but also the ways or styles (schreibstil) of the author in arranging the events of the content of his work. In relation to the nature of comparative literature, Birus suggests that, literary knowledge without comparison is empty, and the comparison of literature without literary knowledge is blind (Allgemeine ohne Vergleichende Literaturwissenschaft ist leer, Vergleichende ohne Allgemeine Literaturwissenschaft ist blind) (http:www.komparatis-tik.unimuenchen.de/ sites/studienfuehrer/html/Kleiner Komparatist.htm). The quotation gives firmness to the existence of a complementary process between literary and comparative literary works. This means that if one work is only reviewed from the cultural side of the author will only produce knowledge related to that culture, but if it is reviewed and juxtaposed with other cultural perspectives, it will form broader knowledge and insights in a cross-cultural context.

The presence of comparative literature provides benefits, among others: (1) as the basis for the study of cross-cultural literary works, (2) as the basis or basis of language skills learning (Sprachfertigkeit-en) namely: listening speaking (Hörverständnis-Sprechfertigkeit), reading-writing (LeseverständnisSchreibfertigkeit), (3) as a means of strengthening character education (PPK). As the basis for cross-cultural text studies, comparative literary works can be 
used to compare cultures between nations. As the basis of language learning, comparative literary works, on the one hand have a uniqueness that is not possessed by other linguistic teaching materials, because the language of literary works has a connotative characteristic (figurative), contains majas, and prioritizes the characteristics of narrative discourse (Kutha Ratna, 2005: 14). On the other hand, language in literary works prioritizes its main function, namely communicative function (Nurgiantoro, 2005: 272), and is suitable to be used to teach language skills. Furthermore, as a means of strengthening character education (PPK), comparative literature works are full of value, which can be used to provide value strengthening for learners as the future generations of the nation in order to become a model for the next generations.

\section{Charakter Education}

The definition of character in accordance with KBBI (1994) is psychological, moral, or ethical traits. In other words, character can be interpreted as a habit or habit, which is an act that is always done. Meanwhile, the term ethics comes from the Ancient Greek "ethikos", meaning "arising from habit" is the main branch of philosophy that studies the value or quality of the study of moral standards and judgments. Ethics includes the analysis and application of concepts such as right, wrong, good, bad, and responsibility (http://id.wikipedia. org/wiki/Etika). Ethics, according to Julian Baginni (2003: 45) is a study of human behavior. What people really do is not ethics, but rather what should be done. Morals, on the other hand, are part of ethics. Moral norms are a number of rules that bind and determine how people should behave. The above opinion provides limitations and distinguishes the substance of the two terminology that are actually different but have a very close relationship. The difference between the two terms lies in what and how. Ethics has to do with what should be done, whereas morals have to do with the rules of how to behave. Or in other words morally related to universally accepted norms in society.

Magnis Suseno (1987: 14, 23), sees ethics as a means of orientation for human efforts to answer a fundamental question: how should I live and act? In relation to this question, answers can be obtained from many parties, such as parents, teachers, customs and traditions, friends, social environment, religion, country, and so on. In this case ethics can help to find an orientation that aims to prevent people from living by participating in parties who want to organize and determine how people should live, but rather so that people can understand for themselves why they should behave and act like this or so. Ethics help people to be more able to account for their lives.

Furthermore, moral terms generally refer to the generally accepted notion of good or bad regarding deeds, attitudes, obligations, and so on; morals, ethics, morals (KBBI, 1994); Morals are usually associated with a value system of how we should live well as human beings. This value system is contained in teachings in the form of admonitions, advices, rules, commandments and the like passed down through generations through certain religions or cultures on how man must live well in order for him to truly be a good human being. In contrast to morality, ethics needs to be understood as a branch of philosophy that speaks of the moral 
values and norms that determine human behavior in life. Value is something that is useful to a person or group of people and therefore that person or group is always trying to achieve it because his achievements give great meaning to himself and his whole life. Norms are human rules and behaviors and actions (http://ste84fredy.blog.com /2009/10/06/9/).

Based on the study of ethics, morals, and norms above, it can be said that the values contained in ethics, morals and norms that form the character of man as a whole.

\section{Discussion}

Language learning materials can be developed from a variety of sources. One of them is through comparative literary works, such as prose, poetry, and drama. These works can be functioned and used as one of the bases in language learning, especially language skills learning: listening (Hörverständnis), speaking (Sprechfertigkeit), reading (Leseverständnis), and writing (Schreibfertigkeit). Language skills learning is integrated. That is, learning one language skill cannot be separated from the other. For example, in learning the ability to listen (Hörverständnis) with comparative literary works, learners are trained to listen to dialogues in plays or poetry arrays through video recorders, imitate or repeat them through speaking skills, record them (write) in notebooks, and then read them according to the rhythm and intonation they listen to appropriately. In learning the ability to speak (Sprechfertigkeit) with comparative literary works, learners are trained to dramatize the text of the play, or proclaim verses of poetry, with the right tone and rhythm. re-narrate the content of poems or short stories that he has read in his own words, and listen to them through role-playing techniques. In learning the ability to read (Leseverständnis) with comparative literary works, learners are conditioned to read verses of poetry or dialogues of drama with the right tone and rhythm, read deeply while marking words that are considered difficult, mark parts that are considered important, read aloud, read aloud together then try to discuss with friends, then encouraged to write what has been discussed in the form of $\mathrm{u}$ or appreciation of literary works. The application of language learning through comparative literary works is certainly adapted to the conditions and needs of students with the learning strategy used is PAIKEM learning strategy (Active Learning, Innovative, Creative, Effective, and Interesting).

Furthermore, the discussion is directed at the depiction of character characters in some examples of literary works as follows may reinforce the presence of moral messages in literary works.

Martin Luther's Fable "Geiz vom Hunde im Wasser" (Dog's Attitude by the Water) (Krusche, 1992: 125), tells the story of a dog standing on the edge of a stream while biting a piece of meat. When he saw his shadow in the water that also bit a piece of meat, his heart's desire to seize the flesh arose. When he opened his mouth to take away, the flesh in his mouth fell and was swept away by the stream, so he lost both (the flesh in his mouth and the flesh of the shadow). In this fable are moral values and teachings "do not covet the property of others, or satisfy yourself with what is in you (do not be greedy)." 
The fable "Witty Duck" tells the story of a fight between the "duckling" (small) and the elephant (large). The fight is eventually won by the "duck" (small, but clever), while the "elephant" (big but stupid) suffers defeat. The story contains educational values about intelligence, critical attitudes, self-esteem, do not underestimate or demean the small and weak, and is a social protest against rulers who ignore the helpless weak (Source: Bunga Rampai Hikayat Lama, Sanusi Pane. Pp. 30-39).

Ilse Aichinger's Short Story "der Gefesselte (The Shackled) tells the story of a shackled character with arms bound, legs held, and ridiculed by the attitude and behavior of the audience who rejoice and cheer watching the beautiful movements performed by the shackled in his shackles with the flow of blood flowing from his stripes. The attitude of the circus owner who wants to capture the attention of the villagers through the circus attractions he performs, who is able to sacrifice the shackled for his popularity. The circus owner even threatened to dismiss or fire any members of the circus who were caught deciding or causing the burning or burning of the shackles. This short story contains the value of education as well as a message of humanity: do not rejoice above the suffering of others or do not sacrifice others for your popularity and pride.

The story of "Garlic" and "Onion" tells the story of the character "garlic" (good character), who is very beautiful and soft-hearted, very polite, polite, diligent and kind. On the contrary, the character "onion" (evil character) has a nasty nature, oppressive, lazy (just relaxing), envious, spiteful, greedy and greedy. The end of the story of "garlic" and "shallot" is the character "garlic" obtains a pumpkin gift from the grandmother, in which contains diamonds, gems, and diamonds are very much, otherwise the character "onion" gets a pumpkin gift from the grandmother, in which there are hundreds and dozens of centipedes, scorpions and rattlesnakes that bite the dead the character "onion" and his mother. This story contains educational values, namely: diligent (do not be lazy), kind (do not envy), patient, diligent and honest. modesty (do not like luxury), humble (don't be arrogant/greedy/greedy). In addition, there is a moral message from The Story of Shallot Garlic Folklore, that is, do not be too greedy and greedy. Everyone has their own sustenance. He who is too greedy will be repaid according to his deeds. Always do good in every behavior, then we will get good and happiness.

Ilse Aichinger's Short Story "Der geöffnete Order (Open Warrant) tells the story of a company commander who wants to capture the attention of his superior commander. He was willing to sacrifice his men for the popularity of his leadership. The commander even ordered his men through the ferocious jungle to deliver a warrant containing the shooting himself. This story contains moral values and teachings about humanity: do not sacrifice others for power.

The short story "Dia Yang Menyerah" by Pramudya Ananta Toer, tells about the issues that stand out in the background of blora community story, namely the problem of insecurity and insecurity in carrying out daily activities. People find it difficult to meet their daily food and drink needs, because they are not guaranteed their safety, so many die of starvation, as a result of the success of the power struggle (Japanese invasion, Independence war, Red army invasion, 
Siliwangi invasion, Dutch invasion, and finally guerrilla war). As a result of poverty and hunger people tend to act anarchist, such as the drilling and looting of shops, offices, and schools. Another cause of insecurity and uneasy is the lack of kinship of the local community, so that many people are easily affected and dragged by the currents of power and used as accomplices of the ruler to destroy the lives of their unfaithful relatives. The messages of humanity revealed implicitly in this short story are put forward by the narrator so that people / communities avoid acts of civility, because the abundance never results in prosperity and prosperity, on the contrary, abundance always results in suffering and misery, crying and tears, poverty and squalor, hunger and nudity, ignorance and backwardness for society. The abundance makes people lose everything: tranquility, tranquility, peace, the lives of their loved ones, property, shelter and shelter.

The short story Rede unter dem Galgen (Speech Under the Gallows) with the background of the place under the gallows tells the story of the ruler who uses his power by sending witnesses and executioners to testify and carry out the hanging of the orator. He does not care about truth and justice. He has abused his power at the expense of one member of his own community for the sake of the popularity of his leadership. The witnesses are willing to be witnesses of lies against the orator as long as they remain trusted by the ruler, so that their position in the government remains firm and steady, without introspection that they are no more righteous, no holier and nobler than the orator, so that they should be the first under the gallows to be punished. Likewise, the executioner who is always ready to carry out the orders of superiors by carrying out a suspended sentence, carrying out his duties without considering right or wrong, whether or not a person is hanged, it is important that he obtains a reward that satisfies himself and his family. The story of Rede Unter dem Galgen contains a moral message and a message of humanity: do not judge others, so that you are not judged, because as a human being everyone must have done wrong.

Pramoedya Ananta Toer's Short Story "Then Born He" tells about social issues that stand out in the background of the story of the community in Blora, namely the problem of poverty, backwardness and ignorance, which is signaled as a result of bad habits that thrive in society, namely gambling, theft, robbery, and murder. To overcome these problems, the warrior group attempted to develop areas: politics, social, economic, education and teaching in the midst of society, but faced severe challenges from the colonial government (gubermen), which resulted in the community returning to its original state. The educational value that can be gleaned from the story is: (1) Diligently studying, (2) Avoid lazy habits, (3) Respect those who are weak, (4) Do not make the house as a place to gamble.

The value of education, ethics and morals in the study of literary works above can be appreciated by learners to be used as a guideline to fortify themselves in resisting the temptations of bad deeds that they encounter in the future, because today many social problems are being struck and will continue to plague if ethical and moral education continues to be ignored in this country. 


\section{Conclusion}

Based on the above study, several conclusions can be drawn as follows: (1) comparative literary works can be functioned and used as one of the bases in the learning of language skills through diction, language style, writing style, and expressions used as a medium of literary works, (2) Depiction of character characters in literary works compared to moral messages implied in them, to trigger the strengthening of character education for students; (3) The importance of the values contained in ethical, moral and norm education for the formation of the character of learners as a whole (4) the results of comparative literary studies can form cross-cultural understanding (Interkulturelle Kompetenz).

\section{Bibliography}

Birus, Hendrik, (1993) Allgemeine und Vergleichende Literaturwissenschaft (Komparatistik), tersedia dalam situs:http:www.komparatistik.unimuenchen.de/sites/studienfuehrer/html/KleinerKomparatist.htm(24/3/ 2008).

Budiatna, Melani, dkk., Membaca Sastra (Pengantar Memahami Sastra untuk Perguruan Tinggi). Magelang: Indonesia Tera, 2002.

Bungin, H.,M., Burhan, Penelitian Kualitatif (Komunikasi, Ekonomi, Kebijakan Publik, dan Ilmu Sosial Lainnya). Jakarta: Kencana Prenada Media Group, 2008.

Creswell, John, W., Research Design (Qualitative, Quantitative, and Mixed Methods Approaches (second edition). Thousand Oaks-London-New Delhi: Sage Publications, 2003.

Djojosuroto, Kinayati, Analisis Teks Sastra dan Pengajarannya. Yogyakarta: Pustaka, 2006.

Endraswara, Suwardi, Metodologi Penelitian Sastra: Epistemologi, Model, Teori dan Aplikasi. Yogyakarta: Pustaka Widyatama, 2003.

Faruk, Pengantar Sosiologi Sastra (dari Strukturalisme Genetik sampai PostModernisme), Yogyakarta: Pustaka Pelajar, 2005.

Kramsch, Claire, Language and Culture, Oxford: Oxford University Press, 1998

Kutha Ratna, Nyoman, Teori, Metode, dan Teknik Penelitian Sastra. Yogyakarta: Pustaka Pelajar, 2004.

, Sastra dan Cultural Studies: Representasi Fiksi dan Fakta. Yogyakarta: Pustaka Pelajar, 2005.

Magnis-Suseno, Frans, Etika Dasar: Masalah-Masalah Pokok Filsafat Moral. Yogyakarta: Penerbit Kanisius, 2007.

Mahayana, Maman S., Bermain dengan Cerpen (Apresiasi dan Kritik Sastra Indonesia). Jakarta: Gramedia Pustaka Utama, 2006.

Matsumoto, David, Pengantar Psikologi Antar Budaya. Yogyakarta: Pustaka Pelajar \& Institut for Community Behavioral Change (ICBC), 2004.

Mayring, Philip, „Qualitative Content Analysis“ Forum Qualitative Research, Vol 1, No.2-June 2000, tersedia dalam Situs http://www.qualitative research.net/fqs-texte/2-002/2-00mayring-e-htm (20/8/2003). 
Nurgiyantoro, Burhan, Teori Pengkajian Fiksi. Yogyakarta: Gadjah Mada University Press, 2005.

Piliang, Yasraf, Amir, Posrealitas: Realitas Kebudayaan dalam Era Posmetafisika. Yogyakarta: Jalasutra, 2004.

Pradopo, Rachmat Djoko, Prinsip-prinsip Kritik Sastra. Yogyakarta: Gadjah Mada University Press, 2007

Pradotokusumo, Partini Sardjono, Pengkajian Sastra. Jakarta: Gramedia Pustaka Utama, 2005.

Saraswati, Ekarini, Sosiologi Sastra: Sebuah Pemahaman Awal. Malang: Bayu Media \& UMM Press, 2003.

Semi, M. Atar, Kritik Sastra, Bandung: Angkasa, 1984.

----------, Anatomi Sastra. Padang: Angkasa Raya, 1988.

-----------, Metode Penelitian Sastra. Bandung: Angkasa, 1993.

Siswantoro, Metode Penelitian Sastra: Analisis Psikologis. Surakarta: Universitas Muhammadyah Press, 2005.

Stanton, Robert, Teori Fiksi (Terjemahan: Sugihastuti dan Rossi Abi Al Irsyad), Yogyakarta: Pustaka Pelajar, 2007.

S. Takdir Alisjahbana, Seni dan Sastra Di tengah-tengah Pergolakan Masyarakat dan Kebudayaan, (Jakarta: PT. Dian Rakyat, 1985).

Sutrisno, Mudji, SJ., Filsafat, Sastra dan Budaya. Jakarta: Penerbit Obor, 1995. -, Ide-Ide Pencerahan. Jakarta: Penetbit Obor, 2004.

Suwondo, Tirto, Studi Sastra (Beberapa Alternatif). Yogyakarya: Hanindita Graha Widya, 2003.

Taylor, Richard, Understanding the Element of Literature, New York: Martin's Press, 1981.

Teeuw, Andreas, Sastra dan Ilmu Sastra (Pengantar Teori Sastra). Jakarta: Pustaka Jaya, 1984.

Toer, Pramoedya Ananta, Realisme Sosialis dan Sastra Indonesia, Jakarta: Lentera Dipantara, 2003.

Wellek, Rene \& Warren Austin, Teori Kesusasteraan (Diindonesiakan oleh Melani Budiatna). Jakarta: PT. Gramedia, 1990. 